\title{
Relationships Between Spruce Budworm Damage and Site Factors in Spruce-Fir-Dominated Ecosystems of Western Upper Michigan
}

\author{
DAVID M. HIX, BURTON V. BARNES ${ }^{1}$, ANN M. LYNCH ${ }^{2}$ AND JOHN A. WITTER ${ }^{1}$ \\ Department of Forestry, University of Wisconsin, 1630 Linden Drive, Madison, WI 53706 \\ (U.S.A.) \\ ${ }^{1}$ School of Natural Resources, University of Michigan, Ann Arbor, MI 48109-1115 (U.S.A) \\ ${ }^{2}$ School of Renewable Resources, University of Arizona, Tucson, AZ 85721 (U.S.A.)
}

(Accepted 8 January 1987)

\begin{abstract}
Hix, D.M., Barnes, B.V., Lynch, A.M. and Witter, J.A., 1987. Relationships between spruce budworm damage and site factors in spruce-fir-dominated ecosystems of western Upper Michigan. For. Ecol. Manage., 21:129-140
\end{abstract}

Damage by the spruce budworm, Choristoneura fumiferana (Clemens), on balsam fir, Abies balsamea (L.) Mill., in local ecosystems (site units) of the Ottawa National Forest (western Upper Peninsula of Michigan, U.S.A.) was studied in relation to site factors. A multi-factor ecological approach was used to distinguish 25 spruce-fir-dominated ecosystems on a variety of different sites, ranging from dry-mesic outwash plains to river floodplains and swamps. Spruce budworm damage on balsam fir appears to be more directly related to site factors (specifically soil type and drainage class) than to stand parameters such as relative dominance or living-plus-dead basal area. Damage on balsam fir was greatest on wetland ecosystems with organic soils and on dryland ecosystems with impeded drainage. The heavy damage on these soils is probably a consequence of shallow rooting habit which predisposes the physiologically mature balsam fir to drought injury, lessened vigor, and a lessened ability to withstand defoliation. Black spruce, Picea mariana (Mill.) B.S.P., also exhibited heavy damage on sites where it is not well adapted, i.e. somewhat excessively drained dryland ecosystems. An understanding of the site factors and the ecosystem classification provide the basis for predicting where the greatest damage can be expected.

\section{INTRODUCTION}

The spruce budworm, Choristoneura fumiferana (Clemens), is the most important insect pest in North American spruce-fir forests, periodically reaching outbreak levels throughout north temperate and boreal forests (Sanders et al., 1985). Damage on balsam fir (Abies balsamea (L.) Mill.) in the Lake States has been extensive since about 1980 (Lynch and Witter, 1985). In 1980, the estimated total dead balsam fir volume on the Ottawa National Forest 


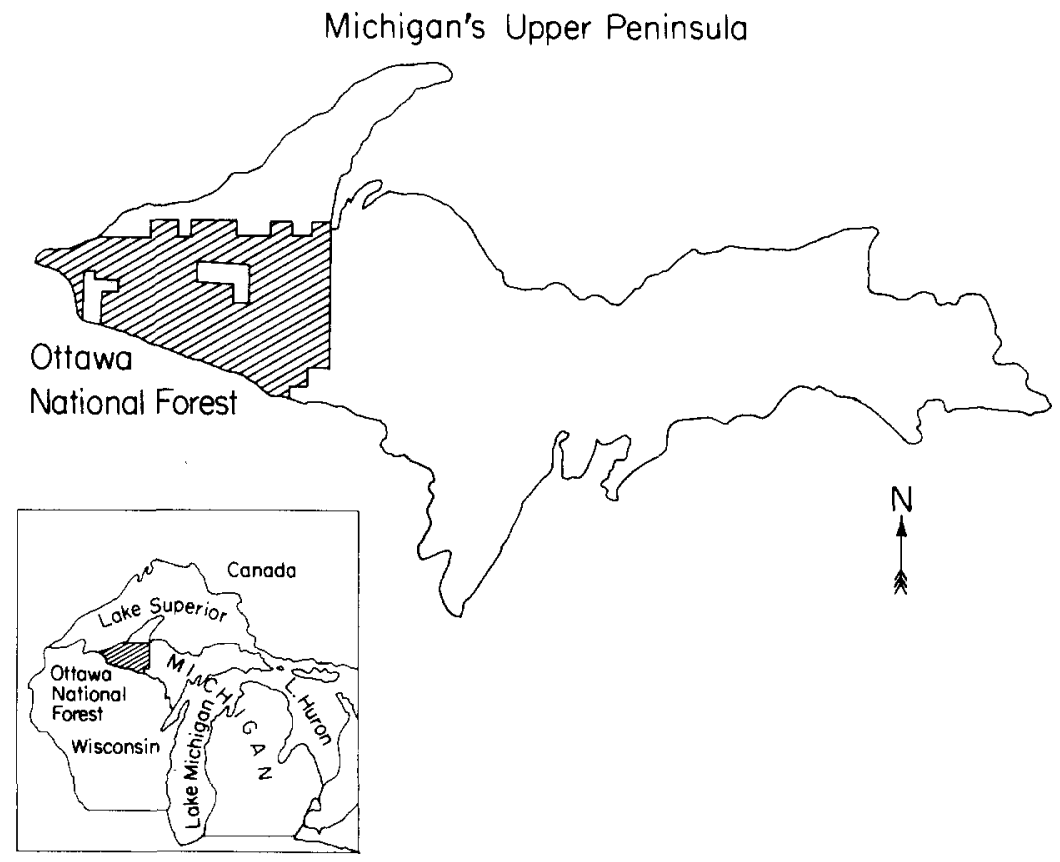

Fig. 1. Location of the study area in the Ottawa National Forest, western Upper Peninsula of Michigan.

(western Upper Michigan) was $288000 \mathrm{~m}^{3}$ (Mog et al., 1982). Damage has been estimated and hazard rating systems developed (Lynch, 1984), but very little is known about the relationships between spruce budworm damage and site factors.

Spruce budworm damage was highly variable among spruce-fir stands of the Ottawa National Forest and damage variables were weakly correlated with stand, site, and soil variables (Lynch and Witter, 1985). However, part of this variation among stands could be due to site factors such as soil moisture. Very dry or very wet sites are associated with greater vulnerability to budworm damage (Coulson and Witter, 1984, p. 330). Thus, our objectives were: (1) to determine and describe the kinds of local ecosystems of the Ottawa National Forest most frequently attacked by the spruce budworm; and (2) to examine in detail the relationships between spruce budworm damage and the site factors of the different ecosystems.

\section{STUDY AREA}

The climate of the Ottawa National Forest (Fig. 1) is continental with a freeze-free growing period of 60 days in the southern portion of the forest increasing to 90 days in the northernmost portion. Precipitation of about 800 $\mathrm{mm}$ is relatively evenly distributed throughout the year. Drift from the last 
glaciation was deposited over Precambrian and Cambrian bedrock (Dorr and Eschman, 1970) about 10000 years ago. Moraines, irregular ice disintegration features of ridges and depressions, and till, outwash, and lake plains dominate the landscape. Wetlands or lakes are now present in most depressions (kettles). Soils vary in texture from sand to clay and are closely related to the physiographic features.

The vegetation of the study area is a highly diverse mosaic of plant communities on dryland (upland) and wetland sites. Northern hardwoods-conifer forests, composed of sugar maple (Acer saccharum Marsh.), yellow birch (Betula alleghaniensis Brit.), basswood (Tilia americana L.), Eastern hemlock ( Tsuga canadensis (L.) Carr.), and, less frequently, American elm (Ulmus americana L.), Eastern hophornbeam (Ostrya virginiana (Mill.) K. Koch) and red oak (Quercus rubra L.) dominate many dryland sites. Pine forests (Eastern white pine, Pinus strobus L.; red pine, $P$. resinosa Ait.; jack pine, $P$. banksiana Lamb.) or pine-oak forests typically occupy the fire-prone, dry sandy areas. Many different kinds of wetlands, from open bogs and marshes to forested swamps, are found in the depressions. Braun (1950) gives a good general description of forests of the region, and specific forest and plant communities are discussed by Spies (1983), Voice (1983) and Spies and Barnes (1985). The area was subject to major human disturbances of logging and fire between about 1850 and the present (Flader, 1983). The species attacked by the spruce budworm, balsam fir, black spruce (Picea mariana (Mill.) B.S.P.), and white spruce ( $P$. glauca (Moench) A. Voss), became established on a wide array of different sites following logging and fire, often on sites they rarely occupied in pre-settlement times.

\section{METHODS}

The Michigan Impact Plot System (MIPS) was established in 1978 and 1979 to quantify the impact of the spruce budworm in the Ottawa National Forest (Mog et al., 1982). A stratified, random, three-stage cluster sampling design was used. The sampling units were: (1) primary sampling unit - a national forest compartment; (2) secondary sampling unit - a spruce-fir stand; and (3) tertiary sampling unit - three concentric circular plots of $0.02,0.04$, and $0.08 \mathrm{ha}$. Two tertiary sample plots were randomly located within each stand. The plots were remeasured annually 1978 to 1984 . The average age of the 42 stands sampled was 51 years (range 31-107). All stands were at least 16 ha in area and were at least $20 \%$ composed of spruce-fir (by number of stems). Balsam fir, white spruce, and black spruce were the major overstory dominants in each stand. Other common species included trembling aspen (Populus tremuloides Michx.), paper birch (Betula papyrifera Marsh.), northern white cedar (Thuja occidentalis L.), Eastern hemlock, and yellow birch. Very few stands were adjacent to each other. 
A multi-factor ecological method (Schlenker, 1964; Spurr and Barnes, 1980, pp. 324-329; Barnes et al., 1982; Barnes, 1984), based on the landscape ecosystem concept of Rowe (1984), was used to distinguish the ecosystem types subject to budworm attack that recur in the Ottawa National Forest (Hix et al., 1983). An ecosystem is a perceivable topographic unit of the landscape, more or less homogeneous both as to the form and structure of the land and as to the vegetation supported thereon (Rowe, 1961, 1962). The method we used is a modification of one that has been applied for over 35 years in BadenWürttemburg, West Germany (Barnes, 1984). In this method, physiography, soil, and overstory, understory, and ground-cover vegetation are used to identify and describe local ecosystems. German researchers (Schlenker, 1964) emphasize that, because areas with a similar ecosystem type have similar physiography, soil, and vegetation, they also exhibit similar silvicultural potential (species choice, cultural treatments), risks of damage from insects, fungi, or windthrow, and growth and yield of tree species. The method has already been successfully applied in several areas of Michigan (Hix, 1983; Pregitzer and Barnes, 1984; Pregitzer and Ramm, 1984; Spies and Barnes, 1985).

In 1982, ecosystem types represented by the MIPS plots were identified and described (Table 1; Hix et al., 1983). Reconnaissance and plot sampling were conducted in 42 stands of the MIPS and in 20 other spruce-fir stands, for an overall total of 99 plots. Rectangular plots $(10 \times 20 \mathrm{~m})$ were used to obtain detailed information on the physiography, soil and vegetation. Detailed descriptions of the data collected and field methods have been described by Hix et al. (1983). Relative dominance (\%) was determined from the sum of living and dead basal area on plot for each species against the total basal area of all species. Procedures used to estimate spruce budworm damage on the sample plots were described by Mog and Witter (1979).

Damage on balsam fir was considered more important than the damage on white spruce and black spruce (Witter et al., 1984). White spruce and black spruce were less important than balsam fir in both relative dominance and incidence of damage.

Analysis of variance was used to test for differences in damage variables among ecosystems, among site factors ( such as topographic position, soil textural class, soil type, soil depth, and soil drainage class ), and between drylands and wetlands. The following variables were calculated for balsam fir, white spruce, and black spruce: relative dominance (\%); living-plus-dead basal area $\left(\mathrm{m}^{2} \mathrm{ha}^{-1}\right)$; and dead basal area $\left(\mathrm{m}^{2} \mathrm{ha}^{-1}\right.$, and \%). Spruce budworm damage was the percentage basal area mortality (dead basal area against living-plusdead basal area ). Another measure of damage, tree mortality (\%), was significantly correlated $\left(r^{2}=0.99, P<0.01\right)$ with basal area mortality for balsam fir; therefore, only basal area mortality is reported here. Because of diversity in site factors and stand composition among the plots, $P=0.20$ was adopted for the level of significance (also used by Lynch and Witter, 1985). 
TABLE 1

Abundance of balsam fir and estimates of balsam fir mortality for dryland and wetland ecosystems of the Ottawa National Forest, Upper Peninsula of Michigan in 1984

\begin{tabular}{|c|c|c|c|c|c|}
\hline & \multirow{2}{*}{$\begin{array}{l}\text { Number } \\
\text { of } \\
\text { plots } \\
(n)\end{array}$} & \multirow{2}{*}{$\begin{array}{l}\text { Relative } \\
\text { dominance } \\
(\%)\end{array}$} & \multicolumn{3}{|l|}{ Basal area } \\
\hline & & & $\begin{array}{l}\text { Living-plus- } \\
\text { dead } \\
\left(\mathrm{m}^{2} \mathrm{ha}^{-1}\right)\end{array}$ & Dead & $\%$ \\
\hline Dryland ecosystems $^{1}$ & 82 & $39.2^{*}$ & $11.0^{*}$ & 3.7 & 31.0 \\
\hline \multicolumn{6}{|l|}{$\begin{array}{l}\text { I. Level to very gently sloping (usually } 0-2 \% \text { ) } \\
\text { A. Somewhat excessively drained to well } \\
\text { drained }\end{array}$} \\
\hline 1. Loamy sand over medium sand & 6 & 35.8 & 9.8 & 1.6 & 17.2 \\
\hline $\begin{array}{l}\text { 2. Cobbly light sandy loam over } \\
\text { medium sand }\end{array}$ & 3 & 38.8 & 6.8 & 0.4 & 9.4 \\
\hline 3. Loamy sand over clay & 1 & 42.8 & 16.2 & 4.9 & 30.4 \\
\hline \multicolumn{6}{|l|}{ B. Moderately well drained } \\
\hline $\begin{array}{l}\text { 4. Loamy sand with fine-textured lower } \\
\text { layers }\end{array}$ & 2 & 54.3 & 15.6 & 8.1 & 55.8 \\
\hline 5. Sandy loam & 4 & 25.7 & 8.2 & 5.2 & 61.4 \\
\hline 6. Loam & 6 & 27.9 & 8.6 & 1.6 & 10.8 \\
\hline 7. Clay & 6 & 41.7 & 10.8 & 6.7 & 72.5 \\
\hline \multicolumn{6}{|l|}{ C. Somewhat poorly drained to poorly drained } \\
\hline 8. Loamy sand & 3 & 28.4 & 10.1 & 2.6 & 31.0 \\
\hline 9. Clay & 3 & 35.6 & 9.1 & 1.0 & 9.1 \\
\hline 10. Sandy loam & 4 & 39.1 & 9.1 & 5.3 & 41.7 \\
\hline \multicolumn{6}{|c|}{ II. Gently to moderately sloping (usually $3-15 \%$ ) } \\
\hline 11. Loamy sand & 7 & 28.3 & 8.8 & 3.3 & 36.0 \\
\hline 12. Sandy loam & 10 & 47.0 & 10.0 & 4.1 & 29.4 \\
\hline 13. Sandy loam over clay loam & 1 & 25.6 & 7.9 & 0.0 & 0.0 \\
\hline 14. Silt loam & 5 & 57.1 & 14.6 & 2.5 & 19.1 \\
\hline 15. Clay & 6 & 45.1 & 12.9 & 3.9 & 23.1 \\
\hline \multicolumn{6}{|l|}{ III. Strongly to steeply sloping (greater than $15 \%$ ) } \\
\hline 16. Loamy sand & 1 & 25.1 & 10.5 & 0.6 & 5.6 \\
\hline 17. Sandy loam & 4 & 43.0 & 16.0 & 6.9 & 54.1 \\
\hline 18. Clay & 2 & 33.3 & 13.9 & 1.3 & 9.7 \\
\hline \multicolumn{6}{|l|}{ IV. Miscellaneous ecosystems } \\
\hline 19. Fire-prone lake and wetland margins & 1 & 36.0 & 14.2 & 0.6 & 4.1 \\
\hline 20. Light sandy loam over bedrock & 2 & 33.7 & 10.7 & 1.9 & 29.4 \\
\hline $\begin{array}{l}\text { 21. Rocky streamsides and river } \\
\text { floodplains }\end{array}$ & 5 & 48.6 & 14.1 & 7.0 & 30.9 \\
\hline Wetland ecosystems $^{1}$ & 17 & $22.6^{*}$ & $6.8^{*}$ & 3.0 & 42.5 \\
\hline 22 . Very infertile swamp on peat & 3 & 0.0 & 0.0 & 0.0 & - \\
\hline $\begin{array}{l}\text { 23. Infertile swamp on peat over mineral } \\
\text { soil }\end{array}$ & 7 & 18.5 & 4.8 & 2.2 & 32.6 \\
\hline $\begin{array}{l}\text { 24. Infertile swamp on muck over } \\
\text { medium sand }\end{array}$ & 2 & 32.2 & 8.5 & 2.9 & 34.0 \\
\hline 25. Moderately fertile swamp on muck & 5 & 37.9 & 13.0 & 6.1 & 57.8 \\
\hline
\end{tabular}

*Means followed by an asterisk $\left({ }^{*}\right)$ are different between the dryland and wetland ecosystems at the 0.20 level of significance (ANOVA).

${ }^{1}$ Total number of plots $(n)$ and means of damage estimates are shown in the columns opposite the appropriate heading for each dryland and wetland ecosystem. 
Correlation coefficients were computed to relate mortality and the various site factors. Soil drainage class, the only variable that was significantly correlated with mortality, was treated as a categorical variable with the somewhat excessively drained class set at 1 and the very poorly drained class set at 6 .

\section{RESULTS AND DISCUSSION}

\section{Stand conditions}

A heterogeneous mix of sites and species was encountered during the examination of the spruce-fir stands. Twenty-five spruce-fir ecosystems were identified and described (Hix et al., 1983). Because of the diverse terrain and the random sampling procedure of MIPS, the ecosystems were diverse with respect to physiography, soil and vegetation, ranging from dry-mesic outwash plains to hydric river floodplains and swamps. Number of plots per ecosystem type were unequal, ranging from 1 to 10 (Table 1). Twenty-one ecosystems were dryland types and four were wetland types. Disturbance in these ecosystems, clear- or partial-cutting typically followed by fire, has resulted in a diverse overstory species composition. The pre-settlement vegetation of each plot, typically a late-successional stage, has been replaced by an early to mid-successional stage. Potential climax dominants differ among the ecosystems in relation to site conditions (Hix et al., 1983). However, the existing overstory of each plot was at least $20 \%$ composed of spruce and fir. The proportions of these species varied considerably in relation to site factors, but balsam fir was found in all of them except ecosystem 22 (very infertile swamp on peat).

\section{Balsam fir abundance and damage related to site factors}

\section{Drylands vs. wetlands}

The relative dominance of balsam fir was significantly greater $(P=0.01)$ on dryland ecosystems (1-21) than on wetland ecosystems (22-25), by $16.6 \%$ (Table 1). Also, the basal area of living-plus-dead balsam fir was significantly greater $(P=0.02)$ on drylands than on wetlands by $4.2 \mathrm{~m}^{2} \mathrm{ha}^{-1}$. However, there was no significant difference $(P>0.20)$ in basal area mortality between wetlands and drylands, although wetland mortality exceeded dryland mortality by $11.5 \%$.

\section{Soil type}

Of three soil types, the relative dominance of balsam fir was significantly greater $(P=0.01)$ on mineral soil than on either organic soil or organic over mineral soil (Table 2). However, there was no significant difference $(P>0.20)$ in basal area of living-plus-dead balsam fir among the soil types, although basal area was greatest on the mineral soil type. The mineral and the organic soil 
TABLE 2

Abundance of balsam fir and estimates of balsam fir mortality for mineral, organic over mineral, and organic soil types, Ottawa National Forest in 1984

\begin{tabular}{|c|c|c|c|c|c|}
\hline \multirow[t]{2}{*}{ Soil type } & \multirow{2}{*}{$\begin{array}{l}\text { Number of } \\
\text { plots }(n)\end{array}$} & \multirow{2}{*}{$\begin{array}{l}\text { Relative } \\
\text { dominance } \\
(\%)\end{array}$} & \multicolumn{3}{|l|}{ Basal area } \\
\hline & & & $\begin{array}{l}\text { Living-plus- } \\
\text { dead } \\
\left(\mathrm{m}^{2} \mathrm{ha}^{-1}\right)\end{array}$ & Dead & $\%$ \\
\hline Mineral & 82 & $39.3 a^{1}$ & 11.0 & 3.8 & $31.4 \mathrm{a}$ \\
\hline Organic over mineral ${ }^{2}$ & 9 & $21.6 \mathrm{~b}$ & 5.6 & 2.4 & $33.0 \mathrm{a}$ \\
\hline Organic & 8 & $23.7 \mathrm{~b}$ & 8.1 & 3.8 & $57.8 \mathrm{~b}$ \\
\hline
\end{tabular}

${ }^{1}$ Means followed by the same letter ( $a$ or $b$ ) are not significantly different at the 0.20 level of significance (ANOVA).

${ }^{2}$ Layer of peat or muck, averaging about $50 \mathrm{~cm}$ thick, over mineral soil.

types had equal amounts of dead basal area $\left(3.8 \mathrm{~m}^{2} \mathrm{ha}^{-1}\right)$. Consequently, the mortality of balsam fir was significantly greater $(P=0.19)$ on the organic soil than on either the mineral soil or the organic over mineral soil.

\section{Soil drainage class}

Balsam fir mortality was significantly correlated with soil drainage class $\left(r^{2}=0.20, P=0.05\right)$. Basal area mortality was greatest on the poorly drained and very poorly drained soil drainage classes, and least on the well-drained class (Table 3 ). However, differences in mortality between individual soil drainage classes were not significant $(P>0.20)$. Thus, there is a trend for damage on balsam fir to be greatest on sites with impeded drainage.

\section{TABLE 3}

Abundance of balsam fir and estimates of balsam fir mortality for soil drainage classes, Ottawa National Forest in 1984

\begin{tabular}{|c|c|c|c|c|c|}
\hline \multirow[t]{2}{*}{ Soil drainage class } & \multirow{2}{*}{$\begin{array}{l}\text { Number of } \\
\text { plots }(n)\end{array}$} & \multirow{2}{*}{$\begin{array}{l}\text { Relative } \\
\text { dominance } \\
(\%)\end{array}$} & \multicolumn{3}{|l|}{ Basal area } \\
\hline & & & $\begin{array}{l}\text { Living-plus- } \\
\text { dead } \\
\left(\mathrm{m}^{2} \mathrm{ha}^{-1}\right)\end{array}$ & Dead & $\%$ \\
\hline Somewhat excessively drained & 9 & 28.4 & 9.4 & 2.6 & 31.6 \\
\hline Well drained & 35 & 39.4 & 10.8 & 3.1 & 24.1 \\
\hline Moderately well drained & 22 & 40.4 & 11.3 & 4.2 & 35.9 \\
\hline Somewhat poorly drained & 11 & 47.9 & 13.7 & 5.5 & 38.9 \\
\hline Poorly drained & 18 & 27.9 & 7.8 & 3.8 & 42.9 \\
\hline Very poorly drained & 4 & 13.4 & 3.9 & 1.4 & 42.1 \\
\hline
\end{tabular}




\section{Individual ecosystems}

The individual ecosystems varied greatly in relative dominance of balsam fir. Significant differences $(P=0.17)$ were found in relative dominance among the ecosystems. However, no significant differences $(P>0.20)$ were found in living-plus-dead basal area (mean $=10.2 \mathrm{~m}^{2}$ ha ${ }^{-1}$, range $0.0-16.2 \mathrm{~m}^{2} \mathrm{ha}^{-1}$ ). Balsam fir was not found in wetland ecosystem 22 (very infertile swamp on peat), and wetland ecosystem 23 (infertile swamp on peat over mineral soil) had the second lowest relative dominance and living-plus-dead basal area among the ecosystems.

Damage on balsam fir appeared to be related to ecosystem type, confirming the relationships between soil type and drainage class and budworm damage described above. Significant differences $(P=0.05)$ in mortality were observed among the 25 ecosystems (Table 1). Ecosystems 4, 5, 7, and 25, with the four highest percentages of mortality, all have impeded soil drainage. Most of the other ecosystems that have impeded drainage (i.e., ecosystems $8,10,21,23$, and 24) had slightly less mortality, although all five of these had mortality greater than or nearly equal to the overall mean for all ecosystems $(32.9 \%)$. However, two other moderately well-drained or poorly drained ecosystems (6 and 9) had substantially less mortality than the mean. Less damage may have occurred on these ecosystems because they represent the most mesic, fertile ecosystem types; balsam fir vigor should be good on such ecosystems. Thus, it appears that spruce budworm damage on balsam fir appears to be greatest on wetland ecosystems with organic soils and on dryland ecosystems with moderate to poor drainage.

\section{White spruce and black spruce abundance and damage related to site factors}

Spruce budworm damage on the two spruce species was much less than on balsam fir, but with damage on black spruce being greater than on white spruce. Living-plus-dead basal area of both species averaged only $2.3 \mathrm{~m}^{2} \mathrm{ha}^{-1} \mathrm{com}-$ pared to $10.2 \mathrm{~m}^{2} \mathrm{ha}^{-1}$ for balsam fir.

White spruce was found only on dryland ecosystems, with one exception being wetland ecosystem 23 (infertile swamp on peat over mineral soil). Relative dominance was significantly greater $(P=0.02)$ on drylands $(9.3 \%)$ than on wetlands $(0.6 \%)$. No significant difference $(P>0.20)$ occurred in mortality among the ecosystems, and there were no significant differences in mortality among either the soil drainage classes or the soil textural classes.

Black spruce was found on a wide range of dryland and wetland ecosystems. The species typically establishes on drylands following fire. Relative dominance was significantly greater $(P=0.01)$ on wetland ecosystems $(29.9 \%)$ than on dryland ecosystems $(6.1 \%)$. Mortality was significantly greater $(P=0.20)$ on organic soil $(50.0 \%)$ than on either mineral soil $(20.4 \%)$ or organic over mineral soil (11.7\%). Black spruce was found only on the lighter 
soil textural classes (sand, loamy sand, and sandy loam) and on organic soils. Mortality was greatest on muck soil $(50.0 \%)$, followed by the sand $(39.5 \%)$ and loamy sand (31.1\%) soil types. Black spruce was found on almost all soil drainage classes (except somewhat poorly drained), but it had the highest mortality on the somewhat excessively drained class (35.4\%) and the lowest on the very poorly drained class $(11.0 \%)$. Therefore, it appears that spruce budworm damage on black spruce is greatest on muck soils and somewhat excessively drained sands or loamy sands.

\section{GENERAL DISCUSSION}

Our interpretation of the results is that trends of greater damage to physiologically mature balsam fir and black spruce exist on sites where their ability to respond (i.e. to form new rootlets and needles) to repeated budworm defoliation is impaired, i.e., sites to which they are least adapted. For balsam fir such sites appear to be those on wetland ecosystems with organic soils and on dryland ecosystems with moderate to poor drainage. On such sites root development may be restricted in depth as compared to well-drained sandy soils. Fowells (1965) reported poor growth of balsam fir in peat swamps. In contrast, black spruce, a species adapted to poorly drained, strongly acidic organic soils, was severely damaged on the somewhat excessively drained sites it had colonized following fire.

Our working hypothesis is that physiologically mature balsam fir and black spruce are subject to more damage on sites where they are least adapted to grow and compete with associated species. Clearly, the correlations between budworm damage and site conditions are not high, and inconsistencies are found in the data. Nevertheless, we believe it is not wise to ignore the trends identified in the results and the observations made in the different ecosystems. A major constraint of the study was that stands of the MIPS were determined randomly, spreading the sample over a great variety of ecosystems (Table 1). With the working hypothesis identified from this initial study, directed sampling of specific ecosystems may be used to test the hypothesis.

The trend of higher budworm damage to balsam fir on organic soils and dryland ecosystems with restricted drainage (moderately well-drained to poorly drained soils ) may be related in part to the rooting characteristics of the species. Defoliation and reduction of photosynthetic area would appear to decrease the supply of photosynthate to the roots, and thus hinder the ability of the tree to develop and maintain an adequate feeding-root system. As a result, water and nutrient uptake would be partially or markedly curtailed, the ability of the crown to produce new foliage would be decreased, and the likelihood of tree mortality would increase. Soil factors such as high water tables (typical of organic soils) or restricted drainage may inhibit deep rooting and leave the 
shallow roots susceptible to drought injury or mortality. An acid push following warm and dry periods may also contribute significantly to root damage and mortality (Ulrich, 1985; Matzner and Ulrich, 1985). Thus, the rooting habits of balsam fir and black spruce appear to be an important consideration.

In a review of the literature on rooting habits of balsam fir, black spruce, and white spruce, Schultz (1969) concluded that regardless of the definition of deep and shallow rooting, these species are considered to be shallow rooted. Research on rooting depth of these species is limited, but balsam fir appears to have a markedly greater potential for deep root development (tap roots and sinker roots) than does black spruce (Zon, 1914; Bannan, 1940; Cheyney, 1942; LeBarron, 1945; Satterlund, 1960; Bakuzis and Hansen, 1965; Fowells, 1965). Field excavations by Schultz (1969) on soils ranging from sand to silt loam textures demonstrated that balsam fir produced distinct tap roots and sinker roots, averaging $0.8 \mathrm{~m}$ and often extending below $1 \mathrm{~m}$. In similar studies with black spruce, he concluded that "the species seemed to produce limited vertical roots under any circumstance". In the greenhouse experiments with seedlings, Schultz reported that the only seedlings of balsam fir to live were those in the sand treatment; all seedlings in the sandy clay loam soils died. Schultz concluded that soils which are not well drained may not be favorable environments for balsam fir seedlings. Our results suggest that balsam fir may be less able to respond to defoliation stress on sites where its rooting depth is restricted, particularly organic soils with high water tables, as compared with well-drained sites. In contrast, the inherently shallow root system of black spruce is usually adequately supplied with water in its typical swamp environment. When it colonizes well-drained sandy sites its shallow root system may come under severe moisture stresses in warm and dry periods.

\section{ACKNOWLEDGEMENTS}

Funding was provided primarily by the USDA Forest Service, North Central Forest Experiment Station; other funding was provided by the Canada/United States Spruce Budworms Program (CANUSA), the McIntire-Stennis Cooperative Forestry Research Act (P.L. 87-788), and The University of Michigan, School of Natural Resources. All are gratefully acknowledged. We thank Mark Teply and Laurie Sloan for field assistance and Tom Mog who directed the establishment of the Michigan Impact Plot System.

\section{REFERENCES}

Bakuzis, E.V. and Hansen, H.L., 1965. Balsam Fir: A Monographic Review. Univ. Minn. Press, Minneapolis, Minn., 445 pp.

Bannan, M.W., 1940. The root systems of northern Ontario conifers growing in sand. Am. J. Bot., 27: $108-114$.

Barnes, B.V., 1984. Forest ecosystem classification and mapping in Baden-Württemburg, West 
Germany. In: J.G. Bockheim (Editor), Forest Land Classification: Experiences, Problems, Perspectives. Proc. Symp. NCR-102 North Central Forest Soils Committee, Society of American Foresters, USDA Forest Service, and USDA Soil Conservation Service, Madison, Wis., March 18-20, 1984, pp. 49-65.

Barnes, B.V., Pregitzer, K.S., Spies, T.A. and Spooner, V.H., 1982. Ecological forest site classification. J. For., 80: 493-498.

Braun, E.L., 1950. Deciduous Forests of Eastern North America. McGraw-Hill, New York, 596 pp.

Cheyney, E.G., 1942. American Silvics and Silviculture. Univ. Minn. Press, Minneapolis, Minn., $472 \mathrm{pp}$.

Coulson, R.N. and Witter, J.A., 1984. Forest Entomology: Ecology and Management. Wiley, New York, $669 \mathrm{pp}$.

Dorr, J.A., Jr. and Eschman, D.F., 1970. Geology of Michigan. Univ. Michigan Press, Ann Arbor, Mich., 476 pp.

Flader, S.L. (Editor), 1983. The Great Lakes Forest, An Environmental and Social History. Univ. Minnesota Press, Minneapolis, Minn., 336 pp.

Fowells, H.A., 1965. Silvics of forest trees of the United States. USDA For. Serv. Agric. Handbook No. 271, Washington, DC, $762 \mathrm{pp}$.

Hix, D.M., 1983. Classification, effects of clearcutting, and management recommendations for forest ecosystems of the Sylvania Recreation Area, Upper Michigan. M.S. Thesis, Univ. Michigan, Ann Arbor, Mich., 207 pp.

Hix, D.M., Barnes, B.V. and Witter, J.A., 1983. Site classification of selected spruce-fir dominated ecosystems of the Ottawa National Forest, Upper Peninsula of Michigan. Mich. Coop. For. Pest Manage. Tech. Rep. 83-14, 89 pp.

Kaufert, F.H., 1935. Heart rot of balsam fir in the Lake States with a special reference to forest management. Minn. Agric. Exp. Stn. Tech. Bull. 110, 27 pp.

LeBarron, R.K., 1945. Adjustment of black spruce root systems to increasing depth of peat. Ecology, 26: 309-311.

Lynch, A.M., 1984. Development of a system to rate spruce-fir stands in Michigan's Upper Peninsula for hazard from the spruce budworm. Ph. D. Thesis, Univ. Michigan, Ann Arbor, Mich., $112 \mathrm{pp}$.

Lynch, A.M. and Witter, J.A., 1985. Relationships between balsam fir mortality caused by the spruce budworm and stand, site, and soil variables in Michigan's Upper Peninsula. Can. J For. Res., 15: 141-147.

Matzner, E. and Ulrich, B., 1985. Implications of the chemical soil conditions for forest decline. Experimentia, 41: 578-584.

Mog, T.P. and Witter, J.A., 1979. Field techniques for assessing the impact of the spruce budworm (Lepidoptera: Tortricidae) in Michigan's Upper Peninsula. Great Lakes Entomol., 12: 213-218.

Mog, T.P., Lynch, A.M. and Witter, J.A., 1982. Impact of the spruce budworm (Lepidoptera: Tortricidae) on the Ottawa and Hiawatha National Forests, 1978-1980. Great Lakes Entomol., 15: 1-24.

Pregitzer, K.S. and Barnes, B.V., 1984. Classification and comparison of the upland hardwood and conifer ecosystems of the Cyrus H. McCormick Experimental Forest, Upper Peninsula, Michigan. Can. J. For. Res., 14: 362-375.

Pregitzer, K.S. and Ramm, C.W., 1984. Classification of forest ecosystems in Michigan. In: J.G. Bockheim (Editor), Forest Land Classification: Experience, Problems, Perspectives. Proc. Symp. NCR-102 North Cental Forest Soils Committee, Society of American Foresters, USDA Forest Service, and USDA Soil Conservation Service, Madison, Wis., March 18-20, 1984, pp. 114-131.

Rowe, J.S., 1961. The level-of-integration concept and ecology. Ecology, 42: 420-427.

Rowe, J.S., 1962. Soil, site and land classification. For. Chron., 38: 420-432. 
Rowe, J.S., 1984. Understanding forest landscapes. Leslie L. Schaffer Forestry Lecture, Univ. British Columbia, Vancouver, B.C., 25 October, 1984.

Sanders, C.J., Stark, R.W., Mullins, E.J. and Murphy, J. (Editors), 1985. Recent Advances in Spruce Budworms Research. Proc. CANUSA Spruce Budworms Research Symp., Canadian Forestry Service and USDA Forest Service, Bangor, Maine, September 16-20, 1984. Canadian Forestry Service, Ottawa, 527 pp.

Satterlund, D.R., 1960. Some interrelationships between ground water and swamp forests in the western Upper Peninsula of Michigan. Ph.D. Dissertation, Univ. Michigan, Ann Arbor, Mich., $171 \mathrm{pp}$.

Schlenker, G., 1964. Entwicklung des Sudwestdeutschland angewandten Verfahrens der forstlichen Standortskunde. In: Standort, Wald und Waldwirtschaft in Oberschwaben. "Oberschwabische Fichtenreviere", Stuttgart, pp. 5-26.

Schultz, J.D., 1969. The vertical rooting habit in black spruce, white spruce, and balsam fir. Ph.D. Thesis, Univ. Michigan Ann Arbor, Mich., 182 pp.

Spaulding, P. and Hansbrough, J.R., 1944. Decay in balsam fir in New England and New York. USDA Bull. 872, $30 \mathrm{pp}$.

Spies, T.A., 1983. Classification and analysis of forest ecosystems of the Sylvania Recreation Area, Upper Michigan. Ph.D. Thesis, Univ. Michigan, Ann Arbor, Mich., 205 pp.

Spies, T.A. and Barnes, B.V., 1985. A multifactor ecological classification of the northern hardwood and conifer ecosystems of Sylvania Recreation Area, Upper Peninsula, Michigan. Can. J. For. Res., 15: 949-960.

Spurr, S.H. and Barnes, B.V., 1980. Forest Ecology. Wiley, New York, 3rd edition, 687 pp.

Ulrich, B., 1985. Interaction of indirect and direct effects of air pollutants in forests. In: C. Troyanowsky (Editor), Air Pollution and Plants. Proc. 2nd Eur. Conf. on Chemistry and the Environment, 21-24 May, 1984, Lindau, West Germany. VCH Publishers, Deerfield Beach, Fla., pp. $149-181$.

Voice, S.P., 1983. Ecological forest site classification and analysis of wetland ecosystems of the Sylvania Recreation Area, Upper Michigan. M.D. Thesis, Univ. Michigan, Ann Arbor, Mich., $218 \mathrm{pp}$.

Wilde, S.A., 1977. Woodlands of Wisconsin. Univ. Wisc. Ext. Publ. G2780, Madison, Wis., 150 pp.

Witter, J., Ostaff, D. and Montgomery, B., 1984. Chapter 4: Damage assessment. In: D.M. Schmitt, D.G. Grimble and J.L. Searcy (Technical Coordinators), Spruce Budworms Handbook: Managing the Spruce Budworm in Eastern North America. USDA Forest Serv., Agric. Handb. 620, pp. 37-64.

Zon, R., 1914. Balsam fir. USDA Agric. Bull. No. 55, 68 pp. 